\title{
PENINGKATAN KOMPETENSI PROFESIONAL DOSEN MENUJU KUALITAS PENDIDIKAN TINGGI AGAMA HINDU DAN SUMBER DAYA MANUSIA HINDU
}

\author{
Oleh \\ I Ketut Tanu \\ Institut Hindu Dharma Negeri Denpasar \\ ketuttanu@gmail.com
}

Diterima 23 Desember 2017, direvisi 20 Januari 2018, diterbitkan 28 Pebruari 2018

\begin{abstract}
The study on increasing lecturer competence is interesting in relation to the dynamics of education and education. Especially in relation to the higher education of Hinduism is also a thing that is still rare to be observed by practitioners of Hindu religious education in particular and education globally in general. With regard to the competence of lecturers in relation to the quality of Hindu religious education the hope is for the realization of the quality of Hindu human resources.

An institution of higher education can be said to have quality, depending on many factors. Many components need to be met in accordance with applicable criteria and conditions. Lately there is a tendency that learners have wisely determine which college option is chosen as a place of college. Physically, that magnificent building can be used as a measure. Then there are also choosing the completeness of facilities owned by the college. In addition, it is also seen that the graduates have the best performance in the regional and national scale. All of that is as the hope and desire of each learner to be able to follow his studies at such higher education institutions.
\end{abstract}

\section{Keyword :}

\section{PENDAHULUAN}

Undang-Undang No. 14 tahun 2005 tentang uru dan Dosen nada menegaskan mengenai kompetensi professional dosen. Beberapa keterampilan bagi dosen antara lain : keterampilan administrasi pendidikan, keterampilan mengunakan media pendidikan, keterampilan metodik dan didaktik, keterampilan memberikan penguatan, dan keterampilan membimbing peserta didik. Tidak itu saja, masih banyak keterampilan yang lainnya yang wajib dipahami dan diterapkan dalam pembelajaran dan pengajaran.

Dengan adanya tenaga dosen yang telah memiliki keterampilan yang memadai, harapannya adalah agar terwujudnya suatu 
lembaga pendidikan tinggi agama Hindu yang berkualitas pula. Kualitas lembaga pendidikan tinggi agama Hindu setidaknya telah memiliki tenaga pengajar yang kualified,. tenaga administrasi yang cakap dan tangap, fasilitas gedung yang memadai, fasilitas perpustakaan yang lengkap, pelayanan akademik dan kemahasiswaan yang tertib, pelaksanaan tri dharma perguruan tinggi yang maksimal, dan mutu tamatan yang siap pakai.

Selanjutnya bahwa dengan kompetensi professional dosen dan adanya kualitas lembaga pendidikan tinggi agama Hindu tersebut dan setelah proses pembelajaran dan pengajaran terealisasi secara optimal, diharapkan dapat melahirkan tamatan yang berkualitas pula yakni terlahirkan sumber daya manusia Hindu yang baik (suputra). Sumber daya manusia Hindu yang diharapkan terakhir dari lembaga pendidikan tinggi agama Hindu, antara lain ; insane sujana yang sraddha dan bhakti kepada Hyang Widhi, menguasai ilmu pengetahuan dan teknologi, berwawasan maju dan berperilaku luwes, berpengalaman dalam tugasnya, loyalitas tinggi dan berdedikasi, berdisiplin dan bersemangat dalma kerja, dan memiliki SDM yang bertanggung jawab dan berprestasi. Beberapa tolak ukur dari SDM Hindu yang kualified seperti tersebut di atas, diharapklan bisa terlahir pada pendidikan tinggi agama Hindu saat ini dan di masa depan.

Berkenaan dengan judul yang tersebut diatas maka ada baiknya dijelaskan mengani apa itu peningkatan, kompetensi, professional, kualitas, pendidikan tinggi, agama Hindu, dan sumber daya manusia. Peningkatan adalah proses, perbuatan, cara meningkatkan, (usaha, kegiatan, dsb). (Tim Penyusun, 1994: 10610). Kompetensi adalah seperangkat pengetahuan, keterampilan, dan perilaku yang harus dimiliki, dihayati, dan dikuasai oleh guru atau dosen dalam melaksanakan tugas keprofesionalan (UU Guru dan Dosen, 2005: 4). Profesional adalah pekerjaan atau kegiatan yang dilakukan oleh seseorang dan menjadi sumber penghasilan kehidupan yang memerlukan keahlian, kemahiran, atau kecakapan yang memnuhi standar mutu dna norma tertentu serta memerlukan pendidikan profesi (UU Guru dan Dosen, 2005: 3). Dosen adalah pendidikan professional dan ilmuwan dengan tugas utama mentransformasikan, mengembangkan, dan menyebarluaskan ilmu pengetahuan, teknologi, dan seni melalui pendidikan, penelitian, dan pengabdian kepada masyarakat (UU Guru dan Dosen, 2005: 3).

Kata kualitas maksudnya adalah tingkat baik buruknya sesuatu; kadar; derajat atau taraf (kepandaian, kecakpaan, dan sebagainya), mutu (Tim Penyusun, 1994: 533). Kemudian dalam UU Sisdiknas 20/2003 pasal 19 (Anonim, 2004: 12-13) dijelaskan tentang "pendidikan tingi merupakan jenjang pendidikan setelah pendidikan menengah yang mencakup program pendidikan diploma, sarjana, magister, spesialis, dan doktor yang diselenggarakan oleh perguruan tinggi". Sedangkan agama Hindu merupakan ajaran yang diyakini oleh umat manusia yang bersumber pada kitab suci Weda. Selanjutnya maksud 'sumber daya manusia' adalah potensi manusia yang dapat dikembangkan untuk proses produksi (Tim Penyusun, 1994: 973). Dalam hal ini adalah kaitannya dengan potensi manusia Hindu yang mampu menjadi pengembang mutu insan-insan atau generasi muda Hindu yang handal dan bertanggung jawab melalui jalur pendidikan agama Hindu. Jadi dapat ditegaskan bahwa maksud topik ini adalah bagaimana usaha untuk meningkatakn mutu profesi atau pekerjaan atau ketermapilan para pendidik pada pendidikan tinggi agama Hindu untuk dapat terwujudkan mutu sumber daya manusia Hindu. Berikut ini dapat disajikan paparan hal tersebut secara sistematis dan berdasarkan sumber-sumber teoretis. 


\section{PEMBAHASAN}

\subsection{Kompetensi Profesional Dosen}

Perkembnagan pendidikan di Indonesia sejalan dengan dinamika tuntunan dan kebutuhan masyarakat itu sendiri. Demikian pula mengani pelaksanaan pendidikan pada berbagai jenjang juga mengalami kemajuan yang searah dengan kebijakan yang telah ditetapkan oleh pemerintah. Salah satu kebijakan yang paling anyar adalah dengan diundangnya tentang undang-undang guru dan dosen nomor 14 tahun 2005, seajak tanggal 6 Desember 2005 lalu. Itu berarti bahwa kesiapan dan kemampuan para tenaga pengajaar (dosen) juga terus dikembangkan, baik secara kemandirian maupun secara melembaga. Berkenaan dengan hal itu, salah satunya adalah agar para dosen memiliki keterampilan yang memadai dalam tugasnya.

Dalam paparan ini akan dijelaskan mengeni beberapa kompetensi professional dosen, antara lain :pertama, keterampilan administrasi pendidikan, kedua, keterampilan menggunakan media pendidikan, ketiga, keterampilan metodik dan didaktik, keempat, keterampilan mengelola kelas, kelima, keterampilan evaluasi pendidikan, keenam, keterampilan memberikan penguatan, dan ketujuh, keterampilan membimbing peserta didik. Ada tujuh keterampilan yang perlu dimiliki oleh seorang dosen untuk meningkatkan keprofesionalannya dalam menjalankan tugasnya. Sekilas uraian tersebut seperti berikut ini.

\section{a. Keterampilan Pendidikan}

Pengajar dituntut untuk memahami dan terampil dalam administrasi pendidikan. Pengajar tidak hanya dituntut terampil dalam mendidik, membimbing, melatih, mengarahkan, dan mengajar peserta didik, tetapi juga dapat mengaktualisasikan keharmonisan dalam pengelolaan pendidikan melalui penguasaan keterampilan di bidang administrasi pendidikan.
Oleh karena administrasi pendidikan menyangkut tentang pembaharuan pendidikan, formulasi umum tentang administrasi pendidikan. Juga tentang tugas kewajiban administratif yang menyangkut program pendidikan, murid atau peserta didik, personil, perkantoran atau tata usaha sekolah/kampus, keuangan atau belanja pendidikan, pelayanan, dan hubungan masyarakat. Kemudia mengenai proses administratif yang dimulai dari membuat putusan, perencanaan, mengorganisasikan, mengkomunikasikan, mengkoordinasikan, mengawasi, menilai atau monitoring dan evaluasi (money). Masih terkait dengan administrasi bahwa supervise, kepemimpinan, dan administrasi sebagai proses sosial pendidikan merupakan bagian yang tak bisa diabaikan. Sebagai administrator juga dituntut pengajar menjadi professional dalam administrasi, serta tetap tenaga fungsional yang paham administrasi dalam era pembaharuan pendidikan.

Sebagai pelaku administrasi (administrator) maka ada beberapa prinsip dasar yang harus diperhatikan yaitu prinsip efisiensi, pengelolaan, pengutamaan tugas pengelolaan, kpeemimpinan yang efektif, dan prinsip kerjasama. Selain itu juga berorientasi pada prinsip kerjasama. Selain itu juga berorientasi pada prinsip fleksibelitas, serta prinsip pendidikan seumur hidup. Lingkup administrasi pendidikan atau sekolah menurut Daryanto (1998: 26-27) meliputi : administrasi program pengajaran, administrasi murid atau siswa, administrasi kepegawaian, administrasi keuangan, administrasi perlengkapan, administrasi pembinaan kesiswaan, dan administrasi hubungan sekolah dengan masyarakat. Bila administrasi itu diterapkan di dalam dunia pendidikan tinggi tentunya pendapat di atas dapat dirujuk dengan menyesuaikan pada kondisi pelaksanaaan administrasi pendidikan pada tingkat pendidikan tinggi.

Berbeda dengan pendapat Subroto (1984) bahwa komponen administrasi pendidikan mencakup administrasi kurikulum, personil, 
murid, tata usaha, sarana pendidikan, dan hubungan sekolah dengan masyarakat. Ada penekanan bahwa tenaga pengajar juga sebagai pelaku administrasi pendidikan yang dinamai administrator. Dalam hal ini sebagai administrator yang terampil dan andal. Kemudian ada pemimpin (leader) sebagai pengendali, pengarah, penanggung para pelaku administrasi pendidikan dalam peran sebagai administrasi, sekaligus pemimpin sebagai pengawas (supervise). Maka dari itu dalam dunia pendidikan tinggi bahwa pengajar menyarankan dua fungsi professional dalam administrasi (koordinator) serta professional juga (supervisor). Cepat atau lambat ada kedua peran itu telah digeluti sebagai tugas dengan professional maka tiba gilirannya sebagai orang top dalam pengelolaan administrasi pendidikan tinggi yakni sebagai pemimpin (leader).

\section{b. Keterampilan Menggunakan Media Pendidikan}

Menurut Oemar Hamalik (1989:5-6) bahwa pengetahuan dan pemahaman tentang media pendidikan serta keterampilan memilih dan menggunakan media pendidikan dinyatakan yakni a) media sebagai alat komunikasi guna lebih mengefektifkan proses belajar mengajar, b) fungsi media dalam rangka mencapai tujuan pendidikan, c) tentang proses-proses belajar, d) hubungan antara metode mengajar dan media pendidikan, e) nilai atau manfaat media pendidikan dalam pengajaran, f) memilih dan menggunakan media pendidikan, g) bebagai jenis alat dan teknik media pendidikan, h) media pendidikan dalam setiap mata pelajaran, i) usaha inovasi dalam media pendidikan, dan lain-lain. Dalam pemilihan media pendidikan kriterianya yakni : a) tujuan mengajar, b) bahan pelajaran, c) metode mengajar, d) tersedianya alat yang dibutuhkan, e) jalan pelajaran,f) penilaiaan hasil belajar, g) pribadi guru, h) minat dan kemampuan siswa, i) situasi pengajaran yang sedang berlangsung.
Kemudian keterampilan membuat media pendidikan (Oemar Hamalik, 1989: 7) syaratnya adalah 1) rasional, sesuai dengan akal dan mampu dipikirkan oleh kita, 2) ilmiah, sesuai dengan perkembnagan akal dan mampu dipikirkan oleh kita, 3) ekonomis, sesuai dengan kemampuan pembiayaan yang ada, dan 4) praktis dapat digunakan dalma kondisi praktek di sekolah dan bersifat sederhana. Jadi dengan pendapat di atas bahwa penggunaan, pemilihan serta bagaimana membuat media pendidikan itu sudah jelas ketentuannya. Tinggal sekarang bagi pengajar (dosen) dapat menyesuasikan dengan kondisi dan situasi pada masing-masing tempat pembelajaran dan pengajaran. Apapun kriteria mengenani media itu pada umumnya selalu ada alasan yakni terbatasnya dana dan kurangnya kemampuan pengajar dalam memanfaatkan media yang ada.

Pandangan Nana Sudjana dan Ahmad Rivai (2002: 1) bahwa metode mengajar dan media pengajaran sebagai alat bantu mengaajr. Sedangkan penilaian adalah alat untuk mengukur atau menentukan taraf tercapai tidaknya tujuan pengajaran. Media pengajaran meliputi grafis, gambar fotografi, media proyeksi, media audio, media tiga dimenasi (sesuai dengan bahan, materi, dan pemanfaatan media secara variasi lebih dari satu media), dan lingkungan sebagai media pengajaran (Menggunakan lingkungan sebagai media murah dan bermanfaat, seperti lapangan, museum, pura, lingkungan desa, dan sebagainya). Dinyatakan bahwa media grafis terdiri atas a) bagan, b) diagram, c) grafik, d) poster, e) kartun, dan f) komik Nana Sudjana dan Ahmad Rivai (2002: 27). Media proyeksi seperti overhead proyektor, slide dan filmstrip. Media audio meliputi media perekaman suara dan sejenis seperti recorder, radio, TV, dan sebagainya.

Menurut Sadiman dkk. (1986: 209-210) bahwa peralatan media pendidikan terdiri atas perlatan proyeksi (optic) sepertioverhead proyektor (OHP), microform eader, 
proyektor film rangkai (film strip projector), proyektor film bingkai (slide projector), proyekor film gelang (film loop projector), proyektor film (motion ficture projector), dan peralatan elektronik seperti radio perekam kaset audio (radio cassette recorder), penalaradio (tuner) perekam pita audio (open reel tape recorder), perekam kaset audio (cassette recorder), amplifier, loudspeaker, perekam kaset audio sinkron (cassete syncrocorder), perekam pita video (video tape recorder), perekam kaset video (video cassette recorder), piringan video (video disk) sambang video (video catridge), video monito, dan proyektor video. Jadi media penddikan juga sangat mennetukan terhadap keberhasilan peserta didik dan pengajar dalam proses pembelajaran dan pengajaran. Maka dari itu bagi pengajar yang baik perlu memiliki dna memanfaatkan media pendidikan yang murah, tepat, dan efektif.

\section{c. Keterampilan Metodik dan Didaktik}

Keterampilan metodik dan didaktik bagi dosen adalah sangat penting, oleh karena keterampilan ini sangat mennetukan keberhasilannya dalam melaksanakan tugas pengajaran atau dalam memberikan kuliah. Terkait dengan metodik bahwa pengajar harus tahu dimana posisinya di kelas, bagaimana sikap dan gayanya, serta metode apa yang tepat digunakan dalam memberikan kuliah. Ada beberapa metode mengajar antara lain : metode ceramah, jawab, diskusi, pemberian tugas, resitasi (perpaduan metode pembelajaran tugas dengan pelaporan hasil tugas), demonstrasi, eksperimen, asodrama dan bermain peran, bekerja dalam kelompok, metode proyek, problem solving, karyawisata, film-strips, dan metode manusi sumber atau resource people (Roestiyah, 1986: 67). Metode mengajar mana yang digunakan itu tergantung materi dan ketermapilan dari dosen iu sendiri. Sedangkan keterampilan didaktik adalah keterampilan pengajar untuk dapat mengenali peserta didik secara baik dna penuh interaktif.

Berkenaan dengan sikap dan gaya pengajar menurut Roestiyah NK (1992: 4143) antara lain : 1) suasana penggambaran temperamen, 2) mengadakan kontak dengan murid berupa cerita, pertanyaan, diskusi, dsbnya, 3) cara menarik perhatian, 4) bersikap antusias terhadap materi pelajaran yang diberikan di kelas, 5) mengahargai dirinya, 6) bicaranya jelas, 7) memperhatikan sifat-sifat khas peserat didik, 8) berpengetahuan dan memberikan perlindungan, 9) menghinddari kekasaran dan suka menghina, 10) kerja sama yang baik, 11) saling berkorelasi dengan vak lain, 12) tidak pilih kasih, dan 13 jauhi ketidaktelitian dan kemalasan.

Adapun keterampilan didaktik adalah keterampilan yang terkait dengan sociomtry yakni bagaimana mengenali peserta didik secara mendalam, memperhatikan, melakukan hubungan atau berteman secara simpati terhadap peserta didik. Untuk bisa menganali karakter peserta didik adalah menjadi kewajiban penting bagi pengajar, tidak saja menyusun tes yang baik, bergaul secara simpati, menerapkan tata tertib atau siasat, tetapi yang utama juga adalah usaha-usaha pengajar melakukan keteladanan setiap hari, melakukan hal yang menyenangkan peserta didik, serta menghindari perilaku yang tidak menyenangkan peserta didik. Kapan pantas diberikan ganjaran dan kapan saatnya diberikan hukuman yang pantas dengan pertimbangan yang matang tanpa adanya sikap emosional.

\section{d. Keterampilan Mengelola Kelas}

Keterampilan mengelola kelas ada dipaparkan oleh EC Wragg dengan judul 'Pengeleolaan Kelas', oleh Michael Marland dengan judul "Seni Mengelola Kelas, Tugas dan Penampilan Seorang Pendidik', serta oleh Hadari Nawawi berjudul 'Organisasi Sekolah dan Pengelolaan Kelas'. Pengajar 
memang dituntut memiliki beragam keterampilan. Tidak saja menguasai ilmu pengetahuan dan teknologi, tetapi juga termasuk paham, cermat, arif, serta terampil dalam mengelola kelas. Ada apa dibalik perlunya pengajar memiliki keterampilan mengelolakelas tersebut. Jawabannya adalah agar tujuan pendidikan tersebut mencapai hasil yang maksimal yakni terwujud peserta didik yang cerdas, cekatan, terampil, berwawasan dan bermoral, bertanggung jawab, serta menjadi kader bangsa Indonesia yang siap menjadi penerus genrasi tuanya.

Berkenaan dengan pengelolaan kelas bahwa ada dua prinsip yang perlu diperhatikan, yakni : 1) pengelolaan kelas adalah segala sesuatu yang dilakukan guru agar anak-anak berpartisipasi aktif dalam kegiatan belajar mengajar, bagaimanapun caranya dan bentuknya; 2) dan berbagai cara untuk menciptakan keadaan dimana anak-anak berpartisipasi aktif dalam kegiatan belajar (EC Wragg, 1996: 8). Pendapat dan menggugah para pengajar atau dosen untuk dapat membangkitkan aktivitas dan kreativitas peserta didik dalam mengikuti pembelajaran di kelas. Tidak ada alasan bagi pengajar untuk tidak mengaktifkan peserta didiknya pada saat memberikan kuliah. Atau jangan sampai hanya pengajar yang aktif sendiri, sedang peserta didik tinggal diam dan lain-lain tanpa ada peran sedikitpun. Jika hal itu terjadi, maka otomatis suasana kelas menjadi pasif dan dapat dikatakan suasananya mati.

\section{e. Keterampilan Evaluasi Pendidikan}

Keterampilan evaluasi pendidikan adalah satu keterampilan bagi pengajar atau dosen untuk dapat melakukan tes atau penilaian terhadap keberhasilan peserat didik dalam mengikuti perkuliahan selama kurun waktu selama satu semester atau sesuai jadwal yang telah ditentukan. Keterampilan ini merupakan keahlian prinsip bagi dosen. Oleh karena materi sajian dalam perkuliahan tersebut harus diketahui hasilnya. Apakah sudah dapat dipahami dan diterapkan atau belum? Dengan pelaksanaan evaluasi pendidikan tersebut, maka dapat diukur tingkat keberhasilan peserta didik maupun pengajar selama kurun waktu yang telah ditentukan. Paling tidak ada tes tengah semester (TTS) atau mid test dan ujian akhir semester (UAS) atau final test.

Mengenai jenis tes dan bentuk tes hasil belajar menurut Mudjijo (1995: 29-30) yakni 1) tes lisan (oral test), 2) tes tertulis (written test) 3) tes tindakan atau perbuatan (performance test). Dalam tes tertulis dapat digunakan beberapa bentuk butir soal, yaitu : 1) tes bentuk uraian (essay test) yang terdiri atas tes uraian bebas dan terikat 2) tes bentuk obyektif (obyektiftest) yang terdiri atas butir tes benar salah (true false), pilihan berganda (multiple choise), isian (Completion), jawaban singkat (short answer), dan menjodohkan (matching). Penggunaan jeni dan bentuk tes disesuaikan dengan kawasan (domain) perilaku peserta didik yang hendak diukur. Karena yang diukur seperti ranah kognitif mencakup: pengatahuan, pemahaman, penerapan, analisis, sintesis dan evaluasi. Ranah aktif mencakup : penerimaan, partisipasi, penilaian atau penentuan sikap, organisasi, dan pembentukan pola hidup. Sedangkan terbimbing, gerakan terbiasa, gerakan kompleks, penyesuaian pola gerakan, dan kreativitas.

Kemudian yang perlu diperhatikan adalah bagaimana melakukan tes atau evaluasi pendidikan dengan ciri-ciri suatu tes hasil belajar yang baik. Menurut Gronlund NE dalam Mudjijo (1995: 40) bahwa sebuah program pengevaluasian harus memiliki beberapa karakteristik umum tertentu. Karakteristikkarakteristik yang paling penting dapat dikelompokkan di bawah judul validity (validitas), reability (keterandalan), dan usability (pemakaian).

Selanjutnya terkait dengan validitas meliputi validitas isi (content validity), validitas yang 
dihubungkan dengan criteria (criterion related validity), seperti teknik korelasi product moment, teknik korelasi diagram pencar, dna teknik rank difference dari Spearman (Rho), serta validitas kualitas tes secara psikologis (construct validity). Tes yang reliability adalah tes yang mantap atau andal digunakan pada waktu, tempat, dan peserta didik yang berbeda, namun hasilnya tetap andal. Keterandalan dapat diukur dari koefisien stabilitas, persamaan, stabilitas dan persamaan, dan konsistensi internal. Kemudahan atau keparktisan tes dilihat dari segi administrasi atau pelaksanaan tes, lamanya waktu tes, pengolahan, penafsiran dan penggunaan hasil. Pemeriksaan hasil tes, tes lain yang pararel atau ekuivalen, dan menyangkut biaya tes. Kemudain analisis butir soal adalah yang berkenaan dengan kuantitas tes seperti tingkat kesukaran butir soalan daya pembeda butir soal.

\section{f. Keterampilan Membimbing Peserta Didik}

Membimbing peserta didik merupakan bagian penting sebab keterampilan bagi pengajar. Membimbing peserta didik adalah tugas yang tidak gampang. Sama halnya dengan mengelola kelas itu perlu seni. Dalam membimbingpun perlu seni. Bila peserta didik yang dibimbing terlalu banyak, maka dirasakan ada kesulitan bagi pengajar. Atau sebaliknya jika yang dibimbing terlalu sedikit, jangan menganggap bahwa membimbing itu sebagai tugas yang enteng. Membimbing perlu keuletan, kesinambungan, ketekunan, juga tugas yang tergolong rutin.

Bilamana pembimbing telah melakukan perannya yakni mengarahkan, menuntun, memberikan solusi, memberikan contoh yang benar, memberikan teladan, serta hal lainnya yang positif bagi bimbingannya, maka hal itu memberikan jalan menuju keberhasilan bagi peserta didik. Tetapi sebaliknya bila yang dibimbing sudah di tuntun dengan baik, tetapi tidak diindahkan, malah dia malas, tugas yang diberikan sering ditunda-tunda, terlalu banyak kesibukan di luar kampus, dan perilaku lainnya yang membuat benih-benih lebih banyak menuju kegagalan yang justru datangnya dari mahasiswa itu sendiri. Lantas siapa yang disalahkan? Disinilah perlu pengertian dan komunikasi dua arah antara pembimbing dengan yang dibimbing. Jadi keterampilan memberikan bimbingan itu sangat penting agar peserta didik menjadi sukses dalam studinya. Perlu diingat bahwa peserta didik perlu taat, disiplin, bertanggung jawab, mengikuti aturan administrasi serta aturan lembaga dengan baik, selalu lincah dan adaptif dengan kondisi atau karakter para pembimbingnya. Jika hal itu diperhatikan, maka peserta didik yakin menjadi orang tersukses dan terbaik dalam masa bimbingnya. Demikian juga para pembimbing jangan sampai mengulur-ngulur atau mencaricari kesalahan para pembimbingnya. Hal itu tidak diinginkan oleh peserta didik maupun dalam aturan lembaga.

\subsection{Kualitas Pendidikan Tinggi Agama Hindu}

Demikian juga halnya dalam pendidikan tinggi agama Hindu, diharapkan pula bisa memenuhi harapan masyarakat untuk menjadi perguruan tinggi yang dapat dijadikan favorit oleh masyarakat. Bila tidak demikian keadaannya, maka perguruan tersebut akan menjadi sepi dan ditinggalkan oleh peminatnya. Perguruan tinggi agama Hindu diharapkan dalam dinamikanya ke depan dapat menjadi tumpuan bagi umat Hindu dalam menimba materi pendidikan agama Hindu. Untuk maksud tersebut, terutama dalam memenuhi kuantitas dan kualitas pendidikan tinggi agama Hindu sudah saatnya sejak dini memperhatikan dan meningkatkan kualitasnya, diantaranya: pertama, tenaga pengajar yang kualified, kedua, tenaga admnistrasi yang cakap dan tangap, ketiga, fasilitas gedung yang memadai, keempat, fasilitas perpustakaan yang lengkap, kelima, pelayanan akademik dan 
kemahasiswaan yang tertib, keenam, pelaksanaan tri dharma perguruan tinggi yang maksimal, dan ketujuh, mutu tamatan yang siap pakai.

\section{a. Tenaga Administrasi yang cakap dan tanggap}

Tenaga kependidikan dalam lembaga pendidikan agama Hindu, mencakup tenaga dosen dan tenaga administrasi. Tenaga dosen merupakan tenaga professional yang bertugas untuk mendidik dan mengajar peserta didik sesuai dengan keahliannya masing-masing. Begitu juga tenaga administrasi adalah tenaga yang secara khusus dipersiapkan untuk mengerjakan tugas-tugas adminisrasi lembaga pendidikan tinggi agama Hindu.

Tenaga administrasi memiliki tugas khusus untuk menangani administrasi kependidkan, meliputi : administrasi akademik yang mencakup administrasi pendidikan dan pengajaran, penelitian, serta pengabdian kepada masyarakat; administrasi umum yang mencakup administrasi tata usaha perlengkapan, kerumahtanggaan, personalia atau kepegawaian, kesejahteraan, keuangan atau belanja perguruan, serta pengadaan sarana dan prasarana lembaga pendidikan; administrasi kemahasiswaan yang mencakup administrasi organisasi kemahasiswaan, administrasi kesejahteraan mahasiswa, administrasi humas dan kerja sama antar lembaga pendidikan tinggi, administrasi persatuan orang tua mahasiswa, administrasi alumni, administrasi minat, bakat dan aktivitas mahasiswa, dan sebagainya; serta administrasi kerjasama dan hubungan luar negeri.

Dalam profesi di bidang administrasi maka dibutuhkan tenaga-tenaga yang siap bekerja secara ulet, tekun, disiplin, berdedikasi, terampil, lincah, tanggap, patuh, cakap, berprestasi, serta setia pada tugasnya di bidang adminitrasi. Semua kriteria itu sebagai modal sukses dalam penyelenggaraan pedidikan di bidang administrasi. Tenaga administrasi tidak dibenarkan cara kerjanya hanya menunggu komando dari pihak atasan saja. Petugas administrasi diperlukan ketekunan dan kreatif kerja yang bertanggung jawab. Atau petugas administrasi mau bekerja hanya menyenangkan pihak atasan semata, hla itu kurang ditoleransi. Tenaga administrasi harus tau job dan dan uraian tugasnya. Apapun tugas yang wajib dikerjaka maka wajib pula diselesaikan dengan baik. Tidak diharapkan bahwa dengan adinistrasi mau bekerja jika ada nilai proyekya, jika tidak bernilai proyek, jobnya dibuat terseok-seok atau lempar batu sembunyi tangan, alias meninggalkan tanggung jawab di bidang tugas administrasi. Petugas administrasi wajib memahami tugasnya masing-masing dengan baik.

\section{b. Sarana Pendidikan yang memadai}

Sarana pendidikan dan pembelajaran snagat menentukan untuk mencapai kesuksesan tujuan pendidikan. Dalam peraturan pemerintahan nomor 19 tahun 2005 dalam halaman 32 telah diatur mengenai standar sarana dna prasarana. Terkait dengan sarana pendidikan dinyatakan "setiap satuan penddikan wajib memiliki sarana yang meliputi perabot, perlatan pendidikan, media pendidikan, buku dan sumber belajar lainnya, bahan habis pakai, serta perlengkapan lain yang diperlukan untuk menunjang proses pembelajaran yang teratur dan berkelanjutan.

Dengan menyimak ketentuan tersebut di atas, maka dengan jelas dinyatakan bahwa lembaga pendidikan wajib memiliki sarana utama dalam menunjang keberhasilan pendidikan. Tanpa sarana, mustahil dapat mengelola pendidikan secara professional. Apalagi menginginkan terwujudnya serta hadirnya dosen-dosen yang professional. Untuk hal itu perlu ditunjang dengan sarana pendidikan yang memadai, jika tidak maka cita-cita sebagai dosen yang professional hanyalah wacana saja.

Dalam mengelola lembaga pendidikan, maka prasarana gedung adalah sangat prinsip 
dan utama dalam persyaratannya. Bagaimana bisa menyelenggarakan tanpa adanya gedung yang dijadikan tempat untuk melakukan proses pembelajaran dan pengajaran. Maka dari itu syarat prasarana gedung adalah sebagai syarat bagi pengelolaan lembaga pendidikan.

Dalam peraturan pemerintah no. 19 tahun 2005 pada pasal 42 ayat (2) halaman 32 ada ditegaskan tentang standar prasarana pendidikan yakni "setiap satuan pendidikan wajib memiliki prasarana yang meliputi lahan, ruang kelas, ruang pimpinan satuan pendidikan, ruang penididk, ruang tata usaha, ruang perpustakaan, ruang laboratorium, ruang bengkel kerja, ruang unit produksi, ruang kantin, instalasi daya dan jasa, tempat berolahraga, tempat beribadah, tempat bermain, tempat rekreasi, dan ruang atau tempat lain yang diperlukan untuk menunjang proses pembelajaran yang teratur dan berkelanjutan".

Jadi prasarana gedung adalah sebagai syarat utama dalam pendidikan. Gedung yang memadai dalam lembaag pendidikan tempat menjamin kelancaran proses dan pengelolaan pendidikan. Tenaga dan gedung menjadi bagian yang saling melengkapi. Bila gedung memadai maka diimbangi juga tenaga pengelola yang memadai, sehinggaprasarana gedung bisa berfunsgi sesuai dengan kebutuhan pendidikan.

\section{c. Pelayanan Akademik \\ Kemahasiswaan Yang Tertib}

dan

Sasaran utama dalam pelayanan adalah peserta didik itu sendiri yakni para mahasiswa dan mahasiswi. Ada dua jenis pelayanan yang utama yakni pelayanan akademik dan pelayanan kemahasiswaan. Yang dipentingkan dalam pelayanan ini adalah adanya ketertiban terhadap seluruh mahasiswa atau mahasiswa. Mengapa pelayanan yang tertib dijadikan tolok ukur dalam memberikan pelayanan? Karena hal itu sering diabaikan dan sering terlupakan dalam prioritas pelayanan.

Pelayanan akademik dimulai dari tingkat terdepan, yakni dari pelayanan para dosen, pelayanan paa pembimbing akademik (PA), pelayanan di tingkat jurusan (ketua dan sekretaris program studi), pelayanan di tingakt jurusan (ketua dan sekretaris jurusan), pelayanan di tingkat fakultas (dengan komando dekan, para pembantu dekna, kabag tata usaha, para kasubag, dan staf pegawai), serta pelayanan di tingkat rektorat (dengan komando rektor, para pembantu rektor, para kepala biro, para kabag, para kasubag, serta para staf pegawi). Semua perangkat atau personil yang bertugas sesuai dengan jobnya masing-masing dituntut melakukan pelayanan akademik yang optimal, teratur, tertib, dan disiplin.

Adapun cakupan pelayanan akademik yang dimaksudkan adalah registrasi atau seleksi penerimaan mahasiswa baru, pelaksanaan orientasi pengenalan kampus (ospek), pelaksanaan upanayana, pelayanan kartu mahasiswa, pelayanan tata tertib mahasiswa, jadwal perkuliahan sesuai kalender akademik dan panduan studi, pelaksanaan kuliah secara tertib, pelaksanaan ujian tengah dan akhir semester(UTS dan UAS), pelaksanaan kuliah kerja lapangan (KKL), pelaksanaan kuliah kerja nyata $(\mathrm{KKN})$, pengajuan judul skripsi dan penentuan pembimbing skripsi, pelaksanaan bimbingan skripsi sesuai pedoman penulisan skripsi, pelaksanaan ujian skripsi, penyelesaian tugas-tugas akhir lainnya sebagai calon wisudawan, penyelesaian transkripsi nilai, akta, dan ijazah, pelaksanaan yudisium dan samawartana, dan pelaksanaan wisuda atau penamatan sesuai dengan jenjang di tiap-tiap fakultas dan pada progam pascasarjana.

Begitu pula menegani pelayanan di bidang kemahasiswaan secara procedural dan structural tidak jauh berbeda dengan pelayanan di bidang akademik. Pelayanan bidang kemahasiswaan memiliki cakupan berupa : pelayanan kesejahteraan mahasiswa atau pelayanan mahasiswa yang berkenaan dengan beasiswa (baik dari jenjang starat satu atau S1, strata S2, dan strata tiga atau S3, juga mengenai pelayanan tentang organisasi kemahasiswaan 
(orkemas), seperti : himpunan mahasiswa program studi (HMPS) untuk tingkat program studi, himpunan mahasiswa jurusan (HMJ) untuk tingkat jurusan, badan perwakilan mahasiswa (BPM) dan badan eksekutif mahasiswa (BEM) untuk tingkat fakultas, serta dewan perwakilan mahasiswa (DPM), pemerintahan mahasiswa (PM), dan unit kegiatan mahasiswa (UKM), pelayanan alumni, dewan penyantun, persatuan orang tua mahasiswa untuk tingkat rektorat.

Dalam membangkitkan minat dan bakat para mahasiswa, maka dilayani dan disalurkan melalui kativitas dan kreativitas setiap mahasiswa melalui unit kegiatan mahasiwa (UKM). Melalui UKM tersebut, para mahasiswa menghimpun diri dan membentuk badan pengurus harian guna memperlancar kinerja pelayanan antara para mahasiswa dengan dosen Pembina UKM serta untuk kesinambungan aktivitas yang dilakukan hubungannya dengan lembaga (dalam hal ini adlaah pihak rektorat melalui perpanjangan tugas pada pembantu rektor tiga selaku penanggung jawab dan seterusnya untuk sampai pada tugas tunggal policy lembaga yakni rektor sebagai pelindung semua aktivitas mahasiswa). Jenis UKM yang eksis diantaranya : UKM Menwa, PMI, Mapala, Pers, Penalaran, Yoga, Upakara, Basket, Tenis Meja, Catur, Badminton, Volley Ball, Dharma Gita, Dharma Wacana, Karate, Pencak Silat, Bahasa Inggris, Drama, Tabuh, Tari, Band, dan Koperasi Mahasiswa.

Guna kelancaran pelayanan bidang akademik dan kemahasiswaa, juga diimbangi dengan pelayanan bidang sarana, prasarana, keuangan, kerumahtanggaan, personil, serta pelayanan umum. Antara pelayanan akademik dna kemahasiswaan tersebut dilengkapi dan disempurnakan melalui pelayanan fasilitas, keuangan, dan kemahasiswaan itu telah tertata rapi, jika pelayanan bidang fasilitas, keuangan, dan umum terabaikan, maka upaya pelayanan itu menjadi sia-sia saja. Jadi dalam menjalankan tugas-tugas pelayanan akademik, umum, dan kemahasiswaan tersebut, rektor dibantu oleh pembantu rektor I, II, dan III untuk melanjutkan policy rektor sampai ke jenjang terdepan serta di bidang administrasi ditangani oleh biro akademik (yang menangani administrasi akademik dan administrasi kemahasiswaan) serta biro umum (yang menangani administrasi umum, perlengkapan atau investaris, keuangan, dan kepegawaian.

\section{d. Pelaksanaan Tri Dharma Perguruan Tinggi yang maksimal}

Mengenai pelaksanaan tri dharma perguruan tinggi adalah program utama bagi perguruan tinggi agama Hindu. Dalam pencapaian agar diupayakan secara maksimal oleh tri sivitas akademika perguruan tinggi. Komponentri dharma perguruan tinggi mencakup : 1) pendidikan dan pengajaran, 2) penelitian, dan 3) pengabdian kepada masyarakat. Ketiga komponen tri dharma perguruan tinggi tersebut merupakan program utama para dosen dan para mahasiswa. Ketiga program tersebut sedapat mungkin bisa diterapkan dan dilaksanakan dalam pengelolaan perguruan tinggi. Oleh karena ketiga kewajiban tersebut bersifat penting sebagai perwujudan kuantitas dan kualitas perguruan tinggi.

Kewajiban antara pendidikan dan pengajaran, penelitian serta pengabdian kepada masyarakat adalah program yang dilakukan secara seimbang oleh setiap peserta didik dan para dosen. Hal ini wajib dipahami dan diterapkan untuk ujuan meningkatkan kuantitas dan kualitas daripada perguruan tinggi yang bersangkutan. Bagi peserta didik dan dosen tidak hanya diwajibkan untuk melaksanakan program pembelajaran dan pengajaran saja, tetapi yang lainnya juga dikembangkan yakni melalui kegiatan penelitian, sehingga materi pembelajaran dan pengajaran menjadi lebih baik. Demikian juga dengan kegiatan pengabdian kepada masyarakat, bahwa hal itu juga untuk menambah wawasan serta 
pengalaman langsung dari masyarakat, maka kegiatan pengabdian kepada masyarakat menjadi bagian yang sama pentingnya bagi peserta didik dan dosen.

Kegiatan pembelajaran dan pengajaran dilakukan di kelas atau di kampus, maka kegiatan penelitian dapat dilakukan diperpustakaan, di lab, di tengah-tengah masyarakat, atau di tempat tertentu sesuai obyek penelitian. Demikian pula dalam kaitannya dengan pengabdian kepada masyarakat dapat dilakukan pada masyarakat akademis seperti di sekolah, kampus, atau lembaga pendidikan baik negeri maupun swasta. Selain itu juga dapat dilakukan pada masyarakat public, baik di pedesaan maupun di perkotaan sesuai jenis program dan jadwal yang telah ditentukan. Khusus untuk perguruan tinggi agama Hindu bahwa pengabdian kepada masyarakat dapat berupa ngayah, KKN, ataupun kerja sosial ke lokasi di masyarakat dalam wujud penanaman pohon penghijauan di sekitar pura, di hutan mangrove, di area perbukitan dan sebagainya. Juga bisa berupa ceramag agama Hindu, dharma tula, pembinaan sekaa pesantian, pembinaan sekaa teruna teruni, pelatihan tukang banten dan pinandita, pelaksanaan pasraman kilat agama Hindu, ngayah dalam perbaikan tempat suci, serta aktivitas lainnya yang bermanfaat dan menyentuh kebutuhan masyarakat luas. Jadi pelaksanaan tri dharma perguruan tinggi dapat diupayakan sesuai dengan rencana dan prioritasnya secara maksimal, sehingga perguruan tinggi agama Hindu menjadi sumber pengalaman belajar terbaik bagi masyarakat dalam upaya peningkatan kualitas sraddha dan bhakti umat Hindu.

\section{e. Mutu Tamatan yang siap pakai}

Dalam hal untuk menciptakan dan melahirkan tamatan perguruan tinggi agama Hindu yang memiliki mutu yakni tamatan yang siap pakai, maka diperlukan upaya yang tepat dan strategis yaitu penyiapan materi pembelajaran sesuai kurikulum yang inovatif, tersedianya tenaga pengajar dan tenaga administrasi yang professional dalam bidangnya, tersedianya sarana dan prasarana yang memadai sesuai kemajuan iptek, dan adanya potensi dan instansi yang siap menerima tamatan perguruan tinggi agama Hindu. Bila keempat hal di atas telah solid secara kebersamaan, maka diyakini bahwa perguruan tinggi agama Hindu menjadi gudang pencetak tenaga terampil, cetakan, cerdas, dan siap dipakai serta siap terjun ke tengah-tengah masyarakat luas tanpa memilih jenis pekerjaan yang akan didapatkannya.

Upaya untuk mewujudkan adanya tamatan perguruan tinggi agama Hindu yang siap pakai telah dilakukan dengan berbagai strategi dan jalan, baik menyangkut peningkatan kualitas dosen, pegawai dan fasilitas yang dibutuhkan untuk itu. setidaknya para tamatan perguruan tinggi agama Hindu telah dibekali materi teoretis dan praktis yang nantinya dapat diamalkan di tenagh-tengah masyarakat luas, baik di lingkungan informal, formal, dna nonformal. Itu berarti pihak lembaga telah melakukan berbagai terobosan agar tamatannya dikatakan layak atau kualified sebagai tenaga pembina, tenaga pengajar, tenaga penyuluh, praktisi agama Hindu, dan tenaga yang sejenisnya dengan itu yang siap melayani dan mengabdi di tengah-tengah masyarakat Hindu.

\section{1) Kualitas Sumber Daya Manusia Hindu}

Salah satu komponen yang sangat meentukan terhadap kualitas pendidikan tinggi agama Hindu adalah dimilikinya sumber daya manusia Hindu yang berkualitas yakni adanya tenaga dosen dengan kompetensi professional. Sumber daya manusia yang berkualitas tersebut merupakan tenaga handal dan terampil yang mampu menggerakkan serta mengelola pendidikan tinggi secara dinamis dan stabil. Dalam pengelolaan pendidikan tinggi diperlukan tenaga pengelola yang cekatan, tanggap, 
cepat dalam bertindak atas dasar pemikiran yang strategis dan kritis, terampil dalam mengelola serta mengendalikan manajemen pendidikan, memiliki kepedulian yang tinggi terhadap kesulitan peserta didik, serta hal lainnya yakni urgen dalam pengelolaan pendidikan tinggi agama Hindu, yakni dimilikinya fasilitas pendidikan yang memadai.

Selain komponen tersebut di atas, maka ada beberapa faktor penting yang turut menentukan keberhasilan dalam pengembangan pendidikan tinggi agama Hindu yakni telah dimilikinya SDM Hindu dengan kualifikasi yang memadai, dengan tujuan untuk dapat mencetak kader-kader Hindu yang berkualitas pula, antara lain : pertama, insane sujana yang sraddha dan bhakti kepada hyang widhi, kedua, menguasai ilmu pengetahuan dan teknologi, ketiga, berwawasan maju dan berperilaku luwes, keempat, berpengalaman dalam tugasnya, kelima, loyalitas tingi dan berdedikasi, keenam, berdisiplin dna bersemangat dalam kerja, ketujuh, dan memiliki SDM yang bertanggung jawab dan berprestasi. Beberapa tolok ukur dari SDMHindu yang kualified seperti tersebut di atas diharapkan bisa terlahir pada pendidikan tinggi agama Hindu saat ini dan di masa depan.

\section{2) Insan Sujana yang Sraddha dan Bhakti kepada Hyang Widhi}

Bila disimak sloka suci dalam Slokantara berikut ini, ada dinyatakan bahwa putra yang baik dan bijak merupakan dambaan setiap keluarga. Juga dalam dunia kependidikan bahwa anak yang cerdas dan arif, memiliki sraddha dan bhakti merupakan cita-cita dari lembaga pendidikan tinggi agama Hindu. caswaridipakecandran prabhate rawidipatikah, Trailokye dipako dharmah suputrah kuladipakah.
Kalinganya, yan ing wengi sang hyang candra sira pinaka damar, yan ring rahina sang hyang rawi pinaka dammar, yang ring tri loka sang hyang dharma pinaka dammar. Kuang yan ing kula, ikang anak suputra dang ning aji. Bulan itu lampu malam. Surya itu lampu dunia di siang hari. Dharma itu ialah lampu di ketiga dunia ini. Dan putra yang baik itu cahaya keluarga. Waktu malam, bukanlah sebagai lampunya, di siang hari suryalah, di ketiga dunia ini dharmalah sebagai lampunya; dan dalam keluarga itu putra yang baik itulah cahayanya. Demikian kata kitab suci (Oka, 1993: 114).

Jadi putra yang utama (suputra) serta anak yang mulai (sujana) adlaah harapan utama dari pengelolaan lembaga pendidikan tinggi agama Hindu. Oleh karena tamatan yang bermutu akan mampu menjadi penerus masa depan bangsa yang lebih baik, dinamis, dan sebagai penerang umat manusia.

\section{3) Menguasai Ilmu pengetahuan dan} Teknologi

Dalam UU Sisdiknas No. 20 tahun 2003 pasal 3 halaman 76 ditegaskan bahwa pendidikan nasional berfungsi mengembangkan kemampuan dan membentuk watak serta peradaban bangsa yang bermartabat dalam rangka mencerdaskan kehidupan bangsa, bertujuan untuk berkembnagnya potensi peserta didik agar menjadi manusia yang beriman dan bertakwa kepada Tuhan Yang MahaEsa, berakhlak mulia, sehat, berilmu, cakap, kreatif, mandiri, dan menjadi warga Negara yang demokratis serta bertanggung jawab.

Dalam tujuan pendidikan nasional tersebut telah ditegaskan bahwa peserta didik diharapkan agar berilmu, cakap dan lainlainnya dimaksudkan agar setiap tamatan dari perguruan manapun wajib memenuhi 
tujuan tersebut. Penguasaan ilmu pengetahuan dan teknologi termasuk juga seni adalah sebagai target utama bagi tamatannya Hal ini dipertegas dalam UU Sisdiknas 20/2003 yakni tentang perkembangan ilmu pengetahuan, teknologi dan seni. Itu berarti bahwa materi tersebut sebagai tujuan bagi tamatan pada lembaga pendidikan di Indonesia.

\section{4) Berpengalaman Dalam Bidangnya}

Dalam studi lebih banyak beakit-rakit untuk menimba pengalaman belajar dan prestasi yang terbaik. Apapun disiplin ilmu yang ditekuni hal itu tidaklah tanpa makna. Banyaklah mencari pengalaman dan melakoni bidang ilmu yang berguna di masa depan. Bila hal itu bisa diwujudkna, maka dapat diyakini bahwa orang yang berpengalamanlah yang pasti unggul dan tampil dalam kemajuan masyarakat di masa depan. Peribahasa menegaskan 'pengalaman adalah guru yang terbaik'. Begitu pula jika pengalaman telah ditimba sebanyak-banyaknya di masa belajar sesuai bidang ilmu yang telah ditekuni, suatu ketika pasti dapat menghasilkan yang terbaik pula. Perguruan tinggi agama Hindu memberikan peluang emas bagi generasi muda Hindu untuk bisa belajar agama Hindu guna menambah pengalaman yang terbaik (pendidikan agama Hindu, hukum Hindu, manggala upacara, pemandu wisata, serta pendidikan bahasa Bali) guna bisa diabdikan di tengah-tengah masyarakat pada umumnya di Indonesia.

\section{5) Loyalitas Tingi dan Berdedikasi}

Dalam sloka 228 dalam Sarasamuscaya berikutini.

Durbalartham balam yasy tyagartham ca parigrahah. Pakascaivapacitarthyam pitarastena putrinah. Nihan sinanggah anak, ikang sasananing anatha, tumulung, kadang kalaran doning saktinya, danakena donya antuknya angarjana, panganening dadidra donyan pasuruhan, ikang mangkana, yatikanak ngaranya.

Yang dianggap anak, adalah orang yang menjadi pelindung orang yang memerlukan pertolongan serta untuk kaum kerabat yang tertimpa kesengsaraan; untuk disedekahkan tujuannya, akan segala hasil usahanya; gunanya ia memasak, menyediakan makanan untuk orang-orang miskin; orang yang demikian itu putra sejati namanya (Kajeng, dkk, 2000: 115)

Dari renungan suci di atas bahwa bagi anak yang sejati yang dilakukan adalah hanya mengabdi, menolong, dan taat terhadap nilai-nilai kemanusiaan. Anak yang demikian merupakan anak yang telah memiliki loyalitas kepada sesama manusia. Apa yang dimiliki itu dapat diabdikan kepada kepentingan kemanusiaan. Anak yang demikian sebagai cita-cita dalam pendidikan tinggi agama Hindu.

\subsection{Berdisiplin dan Bersemangat Dalam Kerja}

Disiplin dalam bertindak, berbicara, dan mencetuskan ide maupun buah pikiran dalam era serba global dna modern ini merupakan ciri utama bagi kader masa depan atau kader harapan suatu lembaga pendidikan. Tidak saja itu, bahwa semangat tinggi dalam menciptakan kerja serta membuka peluang kerja merupakan cita-cita bagi tamatan pada suatu pendidikan. Siapa yang berdisiplin, maka dialah yang kebagian kesempatan mujur dalam peluang kerja. Siapapun yang bisa memacu semangat kerja secara terarah dan positif, maka dari itu tamatan perguruan tinggi agama Hindu juga dituntut untuk dapat memprioritaskan agenda kedisiplinan dan semangat dalam menggapai pekerjaan yang layak, agar hidup yang sejahtera bisa terwujud. 
2.4 Bertanggung Jawab dan Berprestasi

Prinsip profesionalitas dalam profesi guru dan dosen sesuai pasal 7 ayat 1 sub e dan $\mathrm{f}$ dinyatakan "memiliki tanggung jawab atas pelaksanaan tugas keprofesionalan dan memperoleh penghasilan yang ditentukan sesuai dengan prestasi kerja" (UU tentang Guru dan Dosen No. 14 tahun 2005, halaman 7). Dari kutipan itu menyiratkan bahwa profesi guru dan dosen dituntut memiliki tanggung jawab dan prestasi kerja. Begitu juga asuhannya itu sendiri yakni para alumnusnya atau tamatannya juga sama harapannya yakni agar mealumnusnya atau tamatannya juga sama harapannya yakni agar memiliki tanggung jawab yang baik serta memiliki prestasi kerja yang bermutu. Maksudnya bahwa para tamatan pada perguruan tinggi agama Hindu juga mampu menghasilkan tamatan yang bertanggung jawab serta memiliki prestasi yang andal dalam bidangnya.

\section{SIMPULAN}

Perkembangan dalam dunia pendidikan, termasuk juga kemajuan ilmu pengetahuan dna teknologi dalam era global menuntut perhatian pemerintah RI untuk terus berbuat banyak dalam menata dinamika pendidkan tersebut. Salah satu produk tentang pendidikan di Indonesia yang paling anyar adalah dengan dikeluarkannya UU tentang Guru dan Dosen No. 14 tahun 2005. Produk hukum tersebut mengisyaratkan kepada pengelola lembaga pendidikan dari tingkat pendidikan dasar sampai pendidikan tinggi, termasuk juga pendidikan tinggi agama Hindu untuk mempersiapkan tenaga dan sarana prasarana pendidikan yang berkualitas.

Mengelola pendidikan tinggi agama Hindu sesuai aturan dari pemerintah terutama Peraturan Presiden Nomor 1 tahun 2004, memberikan kesempatan emas kepada umat Hindu Indonesia untuk menimba pengetahuan agama Hindu pada lembaga pendidikan tinggi agama Hindu negeri satu-satunya di Bali. Lembaga pendidikan tinggi agama Hindu negeri ini sebagai harapan mulai umat Hindu Indonesia. Selain itu, diharapkan pula agar adanya kualitas sebagai pengelolanya (baik dosen dan pegawai), yang pada akhirnya melahirkan tamatan yang bermutu demi kemajuan pembinaan umat Hindu Indonesia ke depan.

\section{DAFTAR PUSTAKA}

Ali, H. Muhammad, 1983. Guru Dalam Proses Belajar Mengajkar. Bandung : Sinar Baru Algendindo.

Anonim, 2004. Undang-Undang Tentang Sisdiknas dan Peraturan Pelaksanaannya 2000-2004. Jakarta : CV. Tamita Utama.

Anonim, 2004. Undang-Undang Tentang Sisdiknas dan Peraturan Pelaksanaannya 2000-2004. Jakarta : CV. Tamita Utama.

Anonim. 2005. "Undang-Undang Republik Indonesia Nomor 14 Tahun 2005 Tentang Guru dan Dosen. Bandung : Citra Umbara.

Anonim. 2005. "Undang-Undang Republik Indonesia Nomor 20 Tahun 2003 Tentang Sisdiknas. Bandung : Citra Umbara.

Anonim. 2005. "Peraturan Pemerintah Nomor 19 Tahun 2005 Tentang Standar Nasional Pendidikan". Bandung : Citra Umbara.

Anonim, 2006. Undang-Undang Republik Nomor 14 Tahun 2005 Tentang Guru dan Dosen. Bandung : Citra Umbara.

Azizy, A. Qodri A. 2003. Pendidikan (Agama) Untuk Membangun Etika Sosial (Mendidik Anak Sukses Masa Depan : Pandai dan Bermanfaat). Semarang : CV. Aneka Ilmu.

Dana, I.N.2005. "Kompilasi Dokumen Literer 45 Tahun Parisada". Parisada Hindu Dharma Indonesia Pusat Jakarta. 
Daryanto, 1998. Administrasi Pendidikan. Jakarta : Rineka Cipta.

Djamarah, Syaiful Bahri. 2000. Guru dan Anak Didik dalam Interaksi Edukatif. Jakarta : Rineka Cipta.

Effendi, E. Usman dan Juhaya S.Praja. 1984. Pengantar Psikologi. Bandung: Angkasa.

Gordon, Thomas, 1986. Guru Yang Efektif Cara Untuk Mengatasi Kesulitan Dalam Kelas. Jakarta : CV. Radjawali.

Hariono, 2006. "Memahami Manusia : Aspek Jasmani Untuk Rohani”. Artikel dimuat dalam WHD No. 479, Desember 2006.

Idris, Zahara, 1981. Dasar-Dasar Kependidikan. Padang : Angkasa Raya.

Kadjeng, I Nyoman, dkk. 1999. Sarasamuscaya. Surabaya: Paramita.

Marland, 1990. Seni Mengelola Kleas, Tugas dan Penampilan Seorang Pendidik. Semarang : Dahara Prize.

Maswinara, I Wayan. 1997. Bhagawadgita. Surabaya : Paramita.

Maswinara, I Wayan. 1998. Ilmu Pengetahuan dan Spiritual Berdasarkan Veda. Surabaya : Paramita.

MD Dahlan, S. Hamid Hasan, dan A. Moein Moesa, 1989. Model-Model Mengajar. IKIP Bandung-Pusdiklat Perumtel.

Moelyono. Djokosantoso, 2004. Beyond Leadership 12 Konsep Kepemimpinan. Jakarta : Gramedia.

Mudjijo, 1995. Tes Hasil Belajar. Jakarta : Bumi Aksara.

Mudyahardjo, Redja dan Waini Rasyidin, Dasar-Dasar Kependidikan. Ditjen Bimas Hindu dan Buddha dan UT 1992.
Nawawi, 1995. Organisasi Sekolah dan Pengelolaan Kelas. Jakarta: PT. Gunung Agung.

Partowisastro, H. dan Hadisuparto, A. 1984. Diagnosa dan Pemecahan Kesulitan Belajar Jilid I. Jakarta : Erlangga.

Purwanto, M. Ngalim, 1986. Psikologi Pendidikan. Bandung : CV. Remadja Karya.

Rochman, Natawijaya, 1976. Diagnostik Kesulitan Belajar. Jakarta : BP3K.

Roestiyah, 1986. Metodik Didaktik. Jakarta: PT. Bina Aksara.

Russell, Bertrand, 1993. Pendidikan dan Tatanan Sosial. Jakarta : Yayasan Obor Indonesia.

Sadiman, dkk. 1986. Media Pendidikan Penegrtian, Pengembangan dan Pemanfaatannya. Jakarta: CV. Rajawali.

Subroto, 1984. Dimensi-Dimensi Administrasi Pendidikan di Sekolah. Yogyakarta: Bina Aksara.

Sudiyo. 2002. Pergerakan Nasional Mencapai dan Mempertahankan Kemerdekaan. Jakarta : Rineka Cipta.

Sudiyo, 2003. Arus Perjuangan Pemuda Dari Masa ke Masa. Jakarta : Rineka Cipta dan Bina Adiaksara.

Sudjana, Nana dan Ahmad Rivai, Teknologi Pengajaran. Bandung : Sinar Baru Algensindo.

Sudjana, Nana dan Ahmad Rivai, 2002. Media Pengajaran. Bandung : Sinar Baru Algensindo.

Suhartin, RI. 1982. Mengatasi KesulitanKesulitan Belajar Dalam Pendidikan Anak. Jakarta : BPK Gunung Agung. 
Sukardi, Dewa Ketut dan Desak Made Sumiati.

Panduan Perencanaan Karir. Surabaya : Usaha Nasional.

Sumarsono, 1986. Dasar-Dasar Kependidikan. Program Studi Bahasa dan Sastra Indonesia Fakultas Keguruan dan Ilmu Pendidikan Unud Singaraja.

Sunarto dan Ny. B. Agung Hartono. 2002. Perkembangan Peserta Didik. Jakarta : Rineka Cipta.

Suryabrata, Sumadi, 1982. Perkembangan Individu. CV. Rajawali.

Surya M. \& Amin, M. 1981. Pengajaran Remidial. Jakarta : Depdikbud.

Suryosubroto, Drs. B., 1983. Beberapa Aspek Dasar-Dasar Kependidikan. Jakarta: Rineka Cipta.

Sutisna, 1987. Administrasi Pendidikan Dasar Teoritis Untuk Praktek Profesional. Bandung : Angkasa.

Tanu, I. K. (2016). PEMBELAJARAN BERBASIS BUDAYA DALAM MENINGKATKAN MUTU PENDIDIKAN DI SEKOLAH. Jurnal Penjaminan Mutu, 2(1), 34-43.

Thera, Ven Narada Maha, 1980. Orang Tua dan Anak. Jakarta : Aksara Buddhis Mandiri.
Tim Dosen FIP-IKIP Malang, 1980. Pengantar Dasar-Dasar Kependidikan. Surabaya : Usaha Nasional.

Widarma, Gede Kerta. 1996. "Etika Dalam Ajaran Hindu". Artikel dimuat dalam WHD No. 356, November 1996.

Winarno Surachmad \& Anwar Syah, 1979. Psikologi Perkembangan. Depdikbud Jakarta.

Winkel, WS. 1996. Psikologi Pengajaran. Jjakarta : Gramedia.

Wisarja, I. K., \& Sudarsana, I. K. (2017). Praksis Pendidikan Menurut Habermas (Rekonstruksi Teori Evolusi Sosial Melalui Proses Belajar Masyarakat). Indonesian Journal of Educational Research, 2(1), 18-26.

Wisarja, I. K., \& Sudarsana, I. K. (2017). REFLEKSI KRITIS IDEOLOGI PENDIDIKAN KONSERVATISME DAN LIBRALISME MENUJU PARADIGMA BARU PENDIDIKAN. Journal of Education Research and Evaluation, 1(4), 283-291.

Wragg, EC. 1996. Pengelolaan Kelas. Jakarta : PT. Gramedia. 